\title{
Spousal Dictator Game: Household Decisions and Other-Regarding Preferences
}

\author{
Matthew K. Gnagey ${ }^{1}$ (D) Therese C. Grijalva ${ }^{1, *}$ and Rong Rong ${ }^{2}$ \\ 1 Department of Economics, Weber State University, 1337 Edvalson St., Ogden, UT 84408-3807, USA; \\ mattgnagey@weber.edu \\ 2 Department of Resource Economics, University of Massachusetts Amherst, 80 campus center way, \\ Amherst, MA 01003, USA; rrong@umass.edu \\ * Correspondence: tgrijalva@weber.edu
}

Received: 9 August 2018; Accepted: 6 September 2018; Published: 12 September 2018

\begin{abstract}
Using a laboratory experiment, we collected data on dictator giving among student strangers and married couples in a suburban area in the United States. Confirming common belief and prior empirical evidence, we find that giving among spouses is greater than giving among anonymous students. We further investigated factors associated with spousal giving which may provide insight for the development of future theories, or into explaining other-regarding preferences. Our data shows that giving is positively associated with who manages household money and controls household income. This result is robust after controlling for each spouse's personal income and using various econometric specifications. The results suggest that spousal giving may be due to household economic roles in addition to other-regarding preferences.
\end{abstract}

Keywords: dictator game; household economics; spousal giving

\section{Introduction}

Researchers seeking to understand altruistic behavior and social preferences often use the dictator game with real monetary payments to elicit realistic behavior in the laboratory [1]. Consistent findings of positive sharing in the dictator game illustrates a deviation from the expectation of pure self-interested behavior [2-4]. Explanations of dictator giving has included variations in the context and setup of the game [5], as well as social distance of the participants [6-8].

Confirming common belief, dictator giving is typically found to be greater among spouses than with anonymous strangers [9]. Married couples have also demonstrated greater cooperation [10], trust [11] and reciprocity [12]. However, within-couple differences in giving varies by gender [12,13] and by knowledge about household finances [13], lending credence to the hypothesis that other characteristics may influence spousal giving. Broadly, the question remains whether marital giving in a dictator setting is simply due to other-regarding preferences, such as altruism, perceptions of fairness, paternalism, or aversion to inequality, or alternatively can be explained by factors or economic roles within the marriage and household.

Using a laboratory experiment, we collected data on dictator giving among student strangers and married couples in a suburban area in the United States to conduct an exploratory empirical analysis of factors that explain differences in spousal dictator giving. Specifically, does spousal giving in a dictator game depend on demographics, individual preference, or who manages household expenditures? The results of such analysis may provide suggestions for future research, in particular in formulating theories and explaining other-regarding preferences.

In our study, we conducted two separate experiments varying the subject pool. In the first round of experiments, we use anonymous undergraduate college students from Weber State University 
in Ogden, Utah. Later, we ran a public spouse's game similar to [13] (where spouses are indirectly informed of their respective spouses decisions if the dictator game is randomly selected for payment, after which the decision becomes explicit) using married or cohabitating couples living in Ogden, Utah. We find that sharing among paired strangers is comparable to prior research on dictator giving; subjects are more benevolent than what would be predicted by models of rational self-interested agents. By comparison, and not surprisingly, we find statistically higher levels of sharing between spouses, perhaps suggesting more altruism or notions of fairness among married couples than student strangers.

We also explore whether spousal giving is correlated with who controls household finances, and whether there are any differences across gender. We found evidence that amounts gifted or kept are correlated with the spouse that manages household finances, perhaps providing some evidence that monies are handed over to the person who specializes in maintaining household finances. This correlation, however, is asymmetric and depends on gender. First, husbands act deferentially by giving more to their wives if their wives manage household finances. Similarly, husbands will also keep more for themselves if they are the one who manages the household finances.

Our results provide insight about motivations or purposes of financial transfers made by spouses in a dictator game setting, suggesting that amounts transferred are related to the roles or tasks that each spouse has in the household. While we are only able to examine factors that may be correlated with dictator giving, it is possible that fairness, reciprocity, and any other-regarding preferences are affected by these roles as well.

\section{Experimental Methods}

\subsection{Stranger Treatment}

College students from Weber State University in Ogden, Utah were recruited via ORSEE [14] to participate in a laboratory experiment that would take between 60 and $90 \mathrm{~min}$. Students were told that they were guaranteed to earn $\$ 10$, comprised of $\$ 5$ for showing up and $\$ 5$ for participating, and would earn additional money based on decisions made during the experiment. Eleven experimental sessions were conducted between October and November of 2015 at Weber State University (WSU). Ten to twelve students participated in each session, resulting in a sample of 129 total subjects.

Subjects were greeted in a common area before entering the lab. Upon entering the lab, subjects were directed to a partitioned computer terminal. Once seated, the researchers read aloud standard rules for participating in the experiment, such as "no talking", "turn off mobile phones", "raise your hand if you need assistance", etc. The experiment commenced with instructions and a quiz to confirm understanding before proceeding to the experimental tasks.

The experiment consisted of multiple parts commencing with a standard dictator game and followed by four sets of convex time budget (CTB) tasks [15]. This paper is the focus of results from a standard dictator game conducted among anonymous student strangers. Following all experimental tasks a follow-up questionnaire was administered. The z-Tree [16] software was used for all experimental tasks. (a complete description of the experiment is available upon request from the corresponding author).

Before starting the set of incentivized experimental exercises, a researcher went around the room and asked each subject to draw a numbered card, presented face down, that represented the identification (ID) number of an another student in the room. The first question in the experiment was to enter this ID number on the computer screen. This ID number would be the recipient of the dictator game as well as the other experimental tasks. This method enabled all subjects to serve as anonymous dictators and recipients. In the dictator game, each subject was asked to decide how much of $\$ 10$ to keep for him/herself. After subjects had completed all experimental exercises and completed the questionnaire, a bingo cage was used to randomly select an exercise from the set of all experimental tasks to determine final earnings for each subject; this means that the dictator game may or may not have been the chosen exercise for payment. All payments were processed in a private room. If a subject 
received payment because of giving from another participant, the recipient was not told who the giver was. Our method mirrors the literature on dictator giving between anonymous strangers.

\subsection{Spouse Treatment}

We recruited married and unmarried cohabiting couples from Ogden, Utah. Recruiting was done over a two-month period by going door-to-door and placing door hangers for a "family decision study" on the front doors of homes in a residential community (see Appendix A for the sample door hanger). Interested households were instructed to send a text message back to us indicating their preferred session choice for participation. We followed up with each interested household to verify that the participants were couples who currently live at the same address. Each participant was guaranteed a $\$ 25$ completion bonus ( $\$ 50$ per household), and was told additional earnings are possible based on decisions made during the study, which would take $90 \mathrm{~min}$. Couples were given larger completion bonuses than students to compensate them for traveling to campus and the opportunity cost of their time. The literature has found that recipient endowments affect giving [4]. In our experiments, both the dictator and the recipient had equal endowments. It is possible, however, that differences in the completion bonuses could influence giving, acting as an income effect that has been found to increase altruistic giving [17]. Fifteen experimental sessions were conducted between February and April of 2016 at WSU. Six to ten couples participated in each session, resulting in a sample of 188 total subjects, or 94 pairs of couples completing the study. Each session lasted around 60 to $90 \mathrm{~min}$.

Only one out of 94 couples in our sample was a same-sex marriage. As a result, the sample size for the category of same-sex couples was not sufficient for statistical analysis. We include their data in the analysis by coding the higher income person as the "husband". All results reported below remain the same whether we drop this couple or not. Henceforth, regardless of marital status and sex orientation, we will refer to the members of a household as husband and wife.

After checking in with an experimenter, all participants were gathered in one classroom where each partner was randomly given either a red or blue folder containing an identification number, a consent form, the experiment instructions and materials, and paperwork for payment purposes. To ensure common knowledge, the experiment rules and instructions were read aloud (similar to the student stranger rules) to all participants. Additionally, we gave an overhead presentation of the experiment and a demonstration of how participants would indicate their choices on an electronic tablet decision interface. The color-coded folders were used for splitting the couples into separate rooms: the spouses with the blue folder were asked to gather in a neighboring room. Both rooms, therefore, could contain a mix of the male and female members, and no single couple would ever be in the same room. Once everyone was seated, participants in each room proceeded through the experimental stages at their own pace.

The experiment consisted of several parts like the student experiment; first, there was a standard dictator game, followed by four sets of individual CTB tasks. Finally a joint CTB task was completed by both spouses together after being reunited in the same classroom. The standard dictator game is the focus of this paper. A questionnaire was administered after completion of the dictator game and the four sets of individual CTB tasks (like the student setting), and a second survey was completed by the couple together after they had completed their joint CTB task. The individual survey collected data on demographics and financial experience or knowledge, while the couple, or joint, survey collected data on joint household financial experience and decision-making power. The results from the standard dictator game were analyzed using both the individual and joint questionnaires.

Each spouse made their allocation decisions using an Excel Macro program. Like the anonymous student dictator game each spouse was asked to decide how much of $\$ 10$ to keep for him/herself. After subjects had completed all experimental exercises and completed the questionnaires, a bingo cage was used to randomly select an exercise from all experimental tasks to determine final earnings for each subject. All experimental payments were processed in a private room. Our method mirrors 
the literature on public giving between spouses [13] because the bingo cage drawing was completed in the presence of all participants, and upon payment, spouses could deduce their partners' decisions.

\section{Data and Results}

\subsection{The Data}

The individual questionnaires used in the student and spousal settings and following the experimental tasks elicited information on individual demographics, socioeconomic conditions, and knowledge about and experience with financial markets. An additional questionnaire was administered to both spouses who answered the questions together. This joint survey collected information about household savings decisions, money management, bank accounts (joint account or not), and information about which spouse controlled household income.

The set of variables with definitions are presented in Table 1. We present the basic statistics of our student and spouse samples in Table 2. There are some expected differences between students and married persons. The average age of students was 25.66 years old, versus spouses being just under 40 years old. The average of the personal income categories (12 categories in total) was lower for students than is for spouses, placing personal income of students in the range of $\$ 5000$ to $\$ 15,000$, while for each individual spouse the range was $\$ 20,000$ to $\$ 30,000$. In terms of financial savings and loan experience, spouses are more likely to have a retirement account and a mortgage, but students are more likely to have a savings account. The proportion of students having children is about $22 \%$ versus $67 \%$ for spouses.

Table 1. Variable names and descriptions.

\begin{tabular}{|c|c|c|}
\hline Variable & Description & Data Source \\
\hline GIVEAMOUNT & The amount of $\$ 10$ a dictator gave to the recipient & Experiment \\
\hline AGE & Age in years & Individual \\
\hline PERSINCOME & $\begin{array}{l}\text { Personal income by category }(1-12) \text {, in increments of } \\
\$ 5000 \text { for categories } 1-8, \$ 10,000 \text { for categories } 9-11 \text {, } \\
\text { and capping out at above } \$ 70,000 \text { for category } 12 \text {. }\end{array}$ & Individual \\
\hline SMOKER & $\begin{array}{l}\text { Dummy variable equaling } 1 \text { if subject is a smoker, } \\
\text { zero else. }\end{array}$ & Individual \\
\hline BMI & Body mass index calculated as $\mathrm{kg} / \mathrm{m}^{2}$ & Individual \\
\hline RETIREMENT & $\begin{array}{l}\text { Dummy variable equaling } 1 \text { if the subject is saving } \\
\text { for retirement, zero else }\end{array}$ & Individual \\
\hline SAVINGS & $\begin{array}{l}\text { Dummy variable equaling } 1 \text { if the subject has a } \\
\text { savings account, zero else. }\end{array}$ & Individual \\
\hline MORTGAGE & $\begin{array}{l}\text { Dummy variable equaling } 1 \text { if the subject [or a } \\
\text { spouse] has a mortgage, zero else }\end{array}$ & Individual \\
\hline MALE & $\begin{array}{l}\text { Dummy variable equaling } 1 \text { if subject is a male, } \\
\text { zero else }\end{array}$ & Individual \\
\hline CHILDREN & $\begin{array}{l}\text { Dummy variable equaling } 1 \text { if the subject has any } \\
\text { children, zero else }\end{array}$ & Individual \\
\hline MARRIEDYRS & Years married (spouse data only) & Joint \\
\hline SPOUSEMANAGE & $\begin{array}{l}\text { Dummy variable equaling } 1 \text { if one's spouse manages } \\
\text { household income, zero else. Base category is joint } \\
\text { management of household income. }\end{array}$ & Joint \\
\hline SELFMANAGE & $\begin{array}{l}\text { Dummy variable equaling } 1 \text { if the dictator, self, } \\
\text { manages household income, zero else. Base category } \\
\text { is joint management of household income. }\end{array}$ & Joint \\
\hline JOINTBANK & $\begin{array}{l}\text { Dummy variable equaling } 1 \text { if the married couple } \\
\text { has a joint bank account, zero else }\end{array}$ & Joint \\
\hline
\end{tabular}

a Data sources include the experimental task, individual questionnaires, or the joint questionnaire answered by both spouses together. 
Table 2. Basic statistics for students and spouses.

\begin{tabular}{ccccc}
\hline & \multicolumn{2}{c}{ Students $(\boldsymbol{n = 1 2 9 )}$} & \multicolumn{2}{c}{ Spouses $(\boldsymbol{n}=\mathbf{1 8 8})$} \\
\hline Variable & Mean $(\mathrm{SD})$ & Min, Max & Mean $(\mathrm{SD})$ & Min, Max \\
\hline GIVEAMOUNT & $3.73(2.21)$ & 0,10 & $5.75(2.31)$ & 0,10 \\
AGE & $25.66(8.56)$ & 17,59 & $39.66(12.82)$ & 19,74 \\
PERSINCOME & $2.90(2.74)$ & 1,12 & $5.61(3.75)$ & 1,12 \\
SMOKER & $0.28(0.45)$ & 0,1 & $0.47(0.50)$ & 0,1 \\
BMI & $26.03(7.14)$ & $16.60,53.90$ & $28.19(5.78)$ & $17.97,47.34$ \\
RETIREMENT & $0.25(0.43)$ & 0,1 & $0.78(0.42)$ & 0,1 \\
SAVINGS & $0.79(0.41)$ & 0,1 & $0.64(0.48)$ & 0,1 \\
MORTGAGE & $0.53(0.50)$ & 0,1 & $0.84(0.37)$ & 0,1 \\
MALE & $0.48(0.50)$ & 0,1 & $0.50(0.50)$ & 0,1 \\
CHILDREN & $0.22(0.41)$ & 0,1 & $0.67(0.47)$ & 0,1 \\
MARRIEDYRS & - & - & $12.54(10.46)$ & 1,52 \\
SPOUSEMANAGE & - & - & $0.16(0.37)$ & 0,1 \\
SELFMANAGE & - & - & $0.09(0.29)$ & 0,1 \\
JOINTBANK & - & - & $0.83(0.38)$ & 0,1 \\
\hline
\end{tabular}

Responses to the joint survey completed by both spouses together provide information about household financial decisions. Saving for the future is a common action in our sample of married couples, and it could occur through educational savings (57\%) or retirement plans (77\%). Similar to a Pew study in 2008 [18], wives tend to manage the income more frequently than husbands (19\% versus $13 \%)$, yet in our sample the majority of households manage income jointly. A large majority of the couples, $83 \%$, hold a joint bank account.

\subsection{Sharing Differences between Students and Spouses}

Figure 1a,b show the frequency of allocations (transfers) made by dictators ranging in integer amounts between $\$ 0$ (keep all) and $\$ 10$ (transfer all). Few spouses and students keep the entire amount for themselves, but the proportion of students keeping the entire $\$ 10$ is larger than spouses. Conversely, the proportion of students transferring the entire $\$ 10$ to another is smaller than spouses. Among anonymous students, however, we see that a majority of students do indeed share a positive amount of the $\$ 10$ endowment, a common finding in the literature.

Table 3 summarizes allocation decisions for students and spouses with corresponding tests of significance. Not surprisingly, spouses are more likely to transfer a positive amount to their spouse than students are to an anonymous student $(p<0.001)$. Spouses on average transfer just over $\$ 2$ more of the $\$ 10$ endowment to their spouse than do anonymous students to one another $(p<0.001)$. These differences could be the result of other-regarding preferences, differences in game design, ${ }^{1}$ amount of the completion bonuses, or other socioeconomic factors. For comparison with prior research, we also investigated whether gender affects the amount transferred to another individual. First we tested whether the hypothesis that mean allocations for females and males are equal; second, we tested the hypothesis that the proportion of females and males allocating non-zero amounts to the recipient would be equal. For both samples, students and spouses, we were unable to reject the null hypothesis of no difference based on gender ( $p$-values between 0.312 and 0.589 ).

1 We thank two anonymous referees for calling this to our attention. In the student setting, the pairings were random, and the recipient may or may have been the dictator's dictator. In the spouse setting, each spouse was each other's dictator and recipient. Furthermore, the spousal recipients had the ability to respond to the gift after the couple left the lab, implying a multistage game. These differences in game design could affect the amounts transferred. 


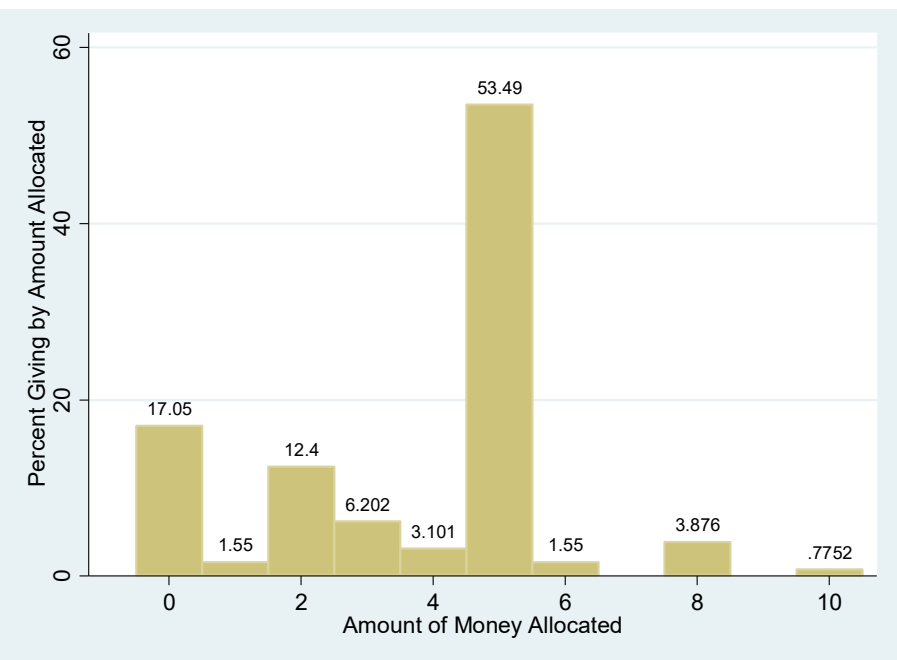

(a)

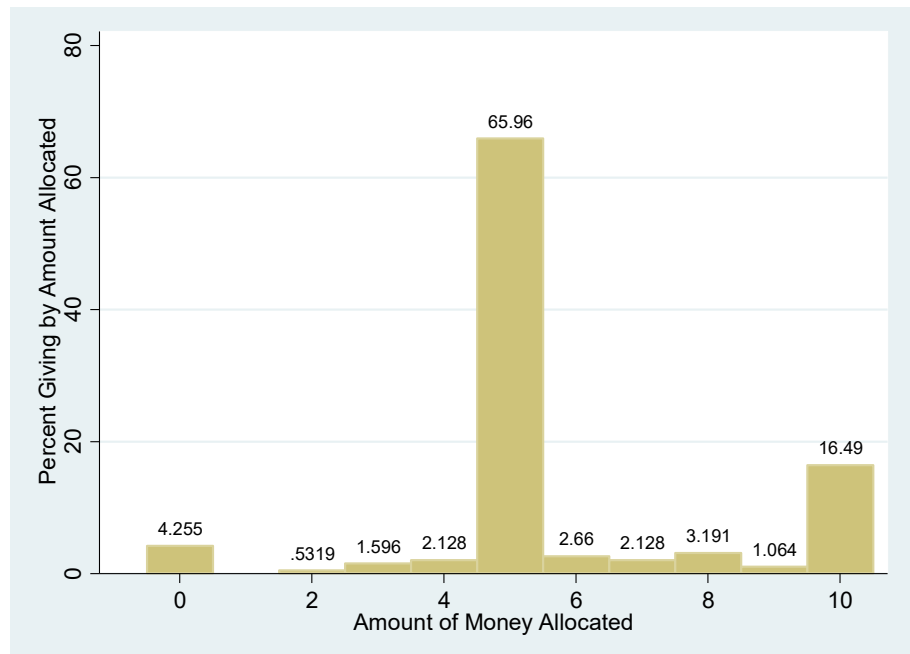

(b)

Figure 1. (a) Allocations by anonymous students $(n=129)$. (b) Allocations by spouses $(n=188)$.

Table 3. Allocation of $\$ 10$ to students and spouses.

\begin{tabular}{cccccc}
\hline \multirow{2}{*}{ Dictator } & \multicolumn{2}{c}{$\begin{array}{c}\text { Dictators with Non-Zero } \\
\text { Allocations (Proportion) }\end{array}$} & \multicolumn{3}{c}{ Amount Allocated } \\
& Mean & Std. Error & Mean & Std. Error & Max \\
\hline Student $(n=129)$ & 0.83 & 0.20 & 3.73 & 0.19 & $\$ 10$ \\
Spouse $(n=188)$ & 0.96 & 0.38 & 5.75 & 0.17 & $\$ 10$ \\
\hline$z$-test of proportions & \multicolumn{2}{c}{$3.90^{\text {a }}(<0.001)$} & & \\
$t$-test of means & \multicolumn{2}{c}{$7.78^{\text {a }}(<0.001)$} \\
\hline
\end{tabular}

a Test statistic with $p$-values in parentheses.

\subsection{Marriage and Money Management}

We explored reasons for the transferred amounts made by spouses. Based on the assumption that a dictator giving between spouses is a financial household decision, we used three measures from the joint survey on household financial decisions-JOINTBANK, SPOUSEMANAGE, and SELFMANAGE- to explore if any of these indicators are related to dictator giving. Table 4 presents the statistical results that test whether joint bank account holders give more than individual bank 
account holders. There appears to be no difference in the proportion of spouses who transfer a positive amount, the entire amount, or mean allocations based on whether the couple holds a joint account.

Table 4. Allocation of $\$ 10$, based on JOINTBANK.

\begin{tabular}{|c|c|c|c|c|c|c|c|}
\hline \multirow[t]{2}{*}{ Dictator } & \multicolumn{2}{|c|}{$\begin{array}{l}\text { Dictators with Non-Zero } \\
\text { Allocations (Proportion) }\end{array}$} & \multicolumn{2}{|c|}{$\begin{array}{l}\text { Dictators Who Transfer } \\
\text { All (Proportion) }\end{array}$} & \multicolumn{3}{|c|}{ Amount Allocated } \\
\hline & Mean & Std. Error & Mean & Std. Error & Mean & Std. Error & Max \\
\hline JOINTBANK = 1 & 0.97 & 0.01 & 0.15 & 0.03 & 5.74 & 0.17 & $\$ 10$ \\
\hline JOINTBANK = 0 & 0.91 & 0.05 & 0.25 & 0.08 & 5.78 & 0.53 & $\$ 10$ \\
\hline $\begin{array}{l}z \text {-test of proportions } \\
t \text {-test of means }\end{array}$ & \multicolumn{2}{|c|}{$1.575^{\mathrm{a}}(0.1152)$} & \multicolumn{2}{|c|}{$-1.420(0.154)$} & \multicolumn{3}{|c|}{$-0.084^{\mathrm{a}}(0.933)$} \\
\hline
\end{tabular}

Table 5 presents the statistical results that test whether the amount transferred to a spouse is based on the recipient spouse managing household income (SPOUSEMANAGE). A spouse is more likely to transfer the entire endowment to their partner who manages the household income, yet the finding of a difference is significant only at the 0.10 level. Mean allocations are statistically different at the 0.05 level based on who manages the household income. The dictator, on average, will transfer $\$ 6.60$ to their spouse if their spouse manages the household income, whereas a dictator will transfer $\$ 5.59$, approximately $\$ 1$ less, to their spouse if their spouse is not solely or primarily responsible for household income. We explore whether males and females behave similarly when their spouse manages household income, and present the results in Table 6. We find that the differences in transfers are driven by husbands.

Table 5. Allocation of $\$ 10$ based on SPOUSEMANAGE.

\begin{tabular}{|c|c|c|c|c|c|c|c|}
\hline \multirow[t]{2}{*}{ Dictator } & \multicolumn{2}{|c|}{$\begin{array}{l}\text { Dictators with Non-Zero } \\
\text { Allocations (Proportion) }\end{array}$} & \multicolumn{2}{|c|}{$\begin{array}{c}\text { Dictators Who Transfer } \\
\text { All (Proportion) }\end{array}$} & \multicolumn{3}{|c|}{ Amount Allocated } \\
\hline & Mean & Std. Error & Mean & Std. Error & Mean & Std. Error & $\operatorname{Max}$ \\
\hline SPOUSEMANAGE = 1 & 1.00 & 0.00 & 0.27 & 0.08 & 6.60 & 0.42 & $\$ 10$ \\
\hline SPOUSEMANAGE = 0 & 0.95 & 0.02 & 0.15 & 0.03 & 5.59 & 0.18 & $\$ 10$ \\
\hline$z$-test of proportions & \multicolumn{2}{|c|}{$1.260^{\mathrm{a}}(0.208)$} & \multicolumn{2}{|c|}{$1.639(0.101)$} & \multicolumn{3}{|c|}{$2.218(0.028)$} \\
\hline
\end{tabular}

a Test statistic with $p$-values in parentheses.

Table 6. Allocation of $\$ 10$ based on SPOUSEMANAGE by gender.

\begin{tabular}{ccccccc}
\hline Dictator & \multicolumn{3}{c}{$\begin{array}{c}\text { Amount Allocated } \\
\text { By Male }\end{array}$} & & \multicolumn{3}{c}{$\begin{array}{c}\text { Amount Allocated } \\
\text { By Female }\end{array}$} \\
\hline & Mean & Std. Error & Max & Mean & Std. Error & Max \\
\hline SPOUSEMANAGE $=1$ & 7.22 & 0.53 & $\$ 10$ & 5.67 & 0.59 & $\$ 10$ \\
SPOUSEMANAGE $=0$ & 5.57 & 0.29 & $\$ 5$ & 5.61 & 0.22 & $\$ 10$ \\
\hline$t$-test of means & \multicolumn{2}{c}{$2.526^{\text {a }}(0.013)$} & $0.090(0.928)$ & \\
\hline \multicolumn{7}{c}{ a Test statistic with $p$-values in parentheses. }
\end{tabular}

We next explore how giving varies based on whether the dictator, him or herself, is responsible for the household income (SELFMANAGE). The results are presented in Table 7. Table 8 presents the results based on gender. Overall, we find statistical differences in giving based on management of the household income, with dictators keeping a larger amount of the \$10 for themselves if they manage the household income; again, this result is driven by husbands (Table 8). Although not presented in Table 8 , we also find that husbands are statistically less likely $(p=0.005)$ to transfer positive amounts to their spouse if they, the husbands, manage the household income. 
Table 7. Allocation of $\$ 10$ based on SELFMANAGE.

\begin{tabular}{|c|c|c|c|c|c|c|c|}
\hline \multirow[t]{2}{*}{ Dictator } & \multicolumn{2}{|c|}{$\begin{array}{l}\text { Dictators with Non-Zero } \\
\text { Allocations (Proportion) }\end{array}$} & \multicolumn{2}{|c|}{$\begin{array}{l}\text { Dictators Who Transfer } \\
\text { All (Proportion) }\end{array}$} & \multicolumn{3}{|c|}{ Amount Allocated } \\
\hline & Mean & Std. Error & Mean & Std. Error & Mean & Std. Error & Max \\
\hline SELFMANAGE $=0$ & 0.97 & 0.01 & 0.09 & 0.29 & 5.86 & 0.17 & $\$ 10$ \\
\hline $\begin{array}{l}z \text {-test of proportions } \\
t \text {-test of means }\end{array}$ & \multicolumn{2}{|c|}{$-2.687^{\mathrm{a}}(0.007)$} & \multicolumn{2}{|c|}{$1.89(0.058)$} & \multicolumn{3}{|c|}{$-1.511(0.132)$} \\
\hline
\end{tabular}

a Test statistic with $p$-values in parentheses.

Table 8. Allocation of $\$ 10$ based on SELFMANAGE by gender.

\begin{tabular}{ccccccc}
\hline Dictator & \multicolumn{3}{c}{$\begin{array}{c}\text { Amount Allocated } \\
\text { By Male }\end{array}$} & \multicolumn{3}{c}{$\begin{array}{c}\text { Amount Allocated } \\
\text { By Female }\end{array}$} \\
\hline & Mean & Std. Error & Max & Mean & Std. Error & Max \\
\hline SELFMANAGE $=1$ & 4.83 & 1.08 & $\$ 10$ & 5.39 & 0.59 & $\$ 10$ \\
SELFMANAGE $=0$ & 6.04 & 0.26 & $\$ 10$ & 5.67 & 0.22 & $\$ 10$ \\
\hline$t$-test of means & \multicolumn{3}{c}{$1.524^{a}(0.130)$} & & $0.529(0.598)$ & \\
\hline \multicolumn{4}{c}{ a Test statistic with $p$-values in parentheses. }
\end{tabular}

Next we conduct probit and tobit regressions. A probit analysis is used to explain $100 \%$ transfers or giving, and a tobit is used to explore the amount transferred, accounting for truncation on both the upper and lower ends at $\$ 0$ (transfer nothing) and $\$ 10$ (transfer all). The results are presented in Table 9. For parsimony, we only present results of the coefficients for key focus variables or those that are statistically significant, but the full set of control variables are presented in Table 1 . The results of both the probit and tobit models support our initial finding after controlling for other factors: dictator giving is positively related to who manages the household income (SPOUSEMANAGE), and that this finding is driven by males. Referring to the probit models in Table 9, the coefficient for SPOUSEMANAGE in the male model is positive and statistically significant at the 0.05 level, whereas the positive coefficient in the female model is not statistically significant. Further, for males only, the coefficient on MORTGAGE is positive and statistically significant at the 0.10 level, while for females only, the coefficients on AGE and SMOKER are negative and statistically significant at the 0.10 and 0.01 levels, respectively. The results from the tobit models are similar. Perhaps one of the most striking results is the lack of statistical significance on the majority of variables across all probit and tobit models, with exception of SPOUSEMANAGE. The lack of evidence provides a glimpse into the reasons of giving. On the one hand, the lack of evidence may simply suggest that a set of unobservables, such as other-regarding preferences, are the main determinant of the giving amount; however, this lack of evidence is offset by a robust finding that giving is positively associated with who manages the household income. This result builds on research on financial decisions within the household such as household bargaining [19,20] and cooperation [12], life insurance purchases [21], household expenditures allocated to benefit one member or another based on who assumes the role of the money manager or family financial officer [22]. 
Table 9. Probit and tobit results (transferring $\$ 10$ to spouse).

\begin{tabular}{|c|c|c|c|c|c|c|}
\hline & \multicolumn{3}{|c|}{ Probit Models } & \multicolumn{3}{|c|}{ Tobit Models } \\
\hline & Model 1 & Model 2 & Model 3 & Model 1 & Model 2 & Model 3 \\
\hline VARIABLES & Households & Males & Females & Households & Males & Females \\
\hline AGE & $\begin{array}{c}0.0035 \\
(0.0156)\end{array}$ & $\begin{array}{c}0.0213 \\
(0.0187)\end{array}$ & $\begin{array}{c}-0.0489 * \\
(0.0283)\end{array}$ & $\begin{array}{c}0.0042 \\
(0.0293)\end{array}$ & $\begin{array}{c}0.0411 \\
(0.0457)\end{array}$ & $\begin{array}{c}-0.0403 \\
(0.0288)\end{array}$ \\
\hline SMOKER & $\begin{array}{l}-0.1150 \\
(0.2165)\end{array}$ & $\begin{array}{c}0.3112 \\
(0.3753)\end{array}$ & $\begin{array}{c}-0.8673^{* * *} \\
(0.3107)\end{array}$ & $\begin{array}{l}-0.4291 \\
(0.4173)\end{array}$ & $\begin{array}{c}0.2302 \\
(0.7514)\end{array}$ & $\begin{array}{c}-1.2227 \text { ** } \\
(0.4654)\end{array}$ \\
\hline BMI & $\begin{array}{c}0.0322 \\
(0.0213)\end{array}$ & $\begin{array}{c}0.0221 \\
(0.0360)\end{array}$ & $\begin{array}{c}0.0600 * * \\
(0.0288)\end{array}$ & $\begin{array}{c}0.0627 \\
(0.0405)\end{array}$ & $\begin{array}{c}0.0267 \\
(0.0729)\end{array}$ & $\begin{array}{l}0.0807+ \\
(0.0467)\end{array}$ \\
\hline MORTGAGE & $\begin{array}{c}0.2350 \\
(0.3309)\end{array}$ & $\begin{array}{l}0.8319 * \\
(0.4811)\end{array}$ & $\begin{array}{l}-0.0093 \\
(0.4771)\end{array}$ & $\begin{array}{c}0.0185 \\
(0.5337)\end{array}$ & $\begin{array}{c}0.5649 \\
(0.7601)\end{array}$ & $\begin{array}{l}-0.1408 \\
(0.6505)\end{array}$ \\
\hline MALE & $\begin{array}{c}0.2851 \\
(0.2427)\end{array}$ & & & $\begin{array}{c}0.3118 \\
(0.4269)\end{array}$ & & \\
\hline SPOUSEMANAGE & $\begin{array}{l}0.5475^{*} \\
(0.3005)\end{array}$ & $\begin{array}{l}1.0036^{* *} \\
(0.4141)\end{array}$ & $\begin{array}{c}0.3513 \\
(0.6542)\end{array}$ & $\begin{array}{l}1.4060 \text { ** } \\
(0.6234)\end{array}$ & $\begin{array}{c}2.5221 * * * \\
(0.8468)\end{array}$ & $\begin{array}{c}0.5544 \\
(0.7936)\end{array}$ \\
\hline SELFMANAGE & $\begin{array}{c}0.3640 \\
(0.3198)\end{array}$ & $\begin{array}{c}0.4455 \\
(0.5415)\end{array}$ & $\begin{array}{c}0.0864 \\
(0.4467)\end{array}$ & $\begin{array}{l}-0.3517 \\
(0.7221)\end{array}$ & $\begin{array}{l}-0.9483 \\
(1.4791)\end{array}$ & $\begin{array}{l}-0.3014 \\
(0.7129)\end{array}$ \\
\hline Constant & $\begin{array}{c}-2.0478^{* *} \\
(0.8380)\end{array}$ & $\begin{array}{c}-2.5709 * \\
(1.3866)\end{array}$ & $\begin{array}{l}-1.3158 \\
(1.1654)\end{array}$ & $\begin{array}{c}4.3132 * * * \\
(1.4989)\end{array}$ & $\begin{array}{c}4.1975 \\
(2.7278)\end{array}$ & $\begin{array}{c}5.5136^{* * * *} \\
(1.5909)\end{array}$ \\
\hline Observations & 188 & 94 & 94 & 188 & 94 & 94 \\
\hline
\end{tabular}

Control variables: PERSINCOME, RETIREMENT, SAVINGS, JOINTBANK, CHILDREN, and MARRIEDYRS. Robust standard errors in parentheses. ${ }^{* * *} p<0.01,{ }^{* *} p<0.05,{ }^{*} p<0.10$.

\section{Conclusions}

There are several studies that explore the differences in behavior related to trust, other-regarding preferences, and cooperation between spouses and anonymous strangers. We contribute to this body of knowledge by comparing dictator giving among anonymous students with giving among spouses from a suburban area in the United States. Similar to the literature, we found evidence that giving among spouses is larger than giving among anonymous students.

Additionally, we investigate factors associated with spousal giving, and find statistical evidence that suggests that giving is positively associated with household money management, specifically with who controls the household income. Thus, we find that financial roles within the household explain transferred amounts, yet the result is primarily driven by the husband's behavior. This result may suggest that other-regarding preferences only partially explain why spouses give larger amounts to their spousal recipients than anonymous students; thus, amounts transferred could be due to economic reasons reflecting financial control within the household.

Author Contributions: T.C.G. and R.R. conceived and designed the experiments; M.K.G., T.C.G., and R.R. performed the experiment; M.K.G., T.C.G., and R.R. identified hypothesis tests and econometric methods; M.K.G. analyzed the data; and M.K.G., T.C.G., and R.R. wrote the paper.

Funding: This research would not have been possible without funding from two Hemingway Family Grants at Weber State University, Ogden, UT 84408.

Conflicts of Interest: The authors declare no conflict of interest. 


\section{Appendix A}

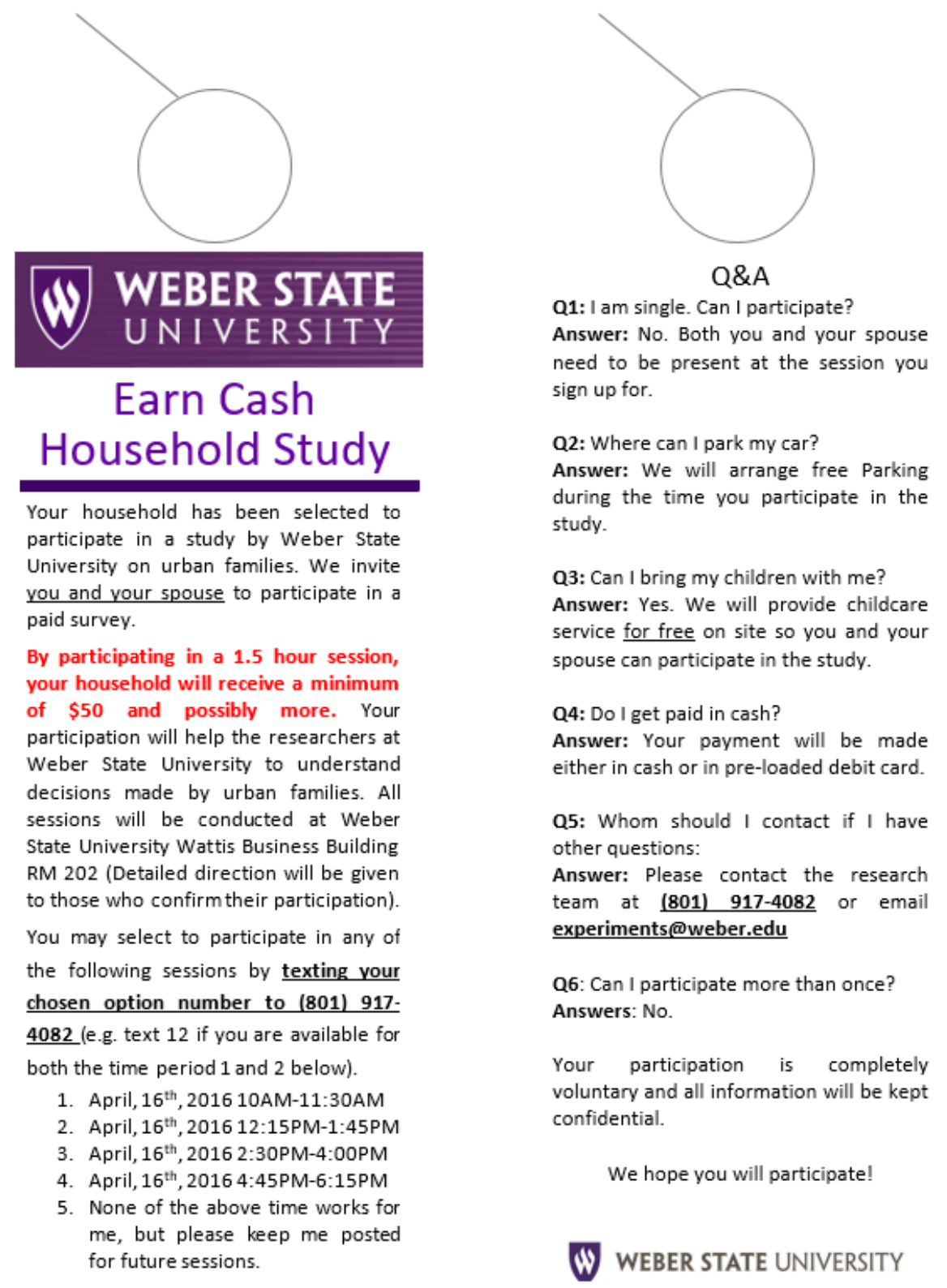

Figure A1. Content on Recruitment Door Hanger.

\section{References}

1. Kahneman, D.; Knetsch, J.L.; Thaler, R.H. Fairness as a Constraint on Profit Seeking: Entitlements in the Market. Am. Econ. Rev. 1986, 76, 728-741.

2. Henrich, J.; Boyd, R.; Bowles, S.; Camerer, C.; Fehr, E.; Gintis, H.; McElreath, R. In Search of Homo Economicus: Behavioral Experiments in 15 Small-Scale Societies. Am. Econ. Rev. 2001, 91, 73-78. [CrossRef]

3. Camerer, C.F. Behavioral Game Theory: Experiments in Strategic Interaction; Sage: New York, NY, USA, 2003.

4. Engel, C. Dictator Games: A Meta Study. Exp. Econ. 2011, 14, 583-610. [CrossRef]

5. Krupka, E.L.; Weber, R.A. Identifying Social Norms Using Coordination Games: Why Does Dictator Game Sharing Vary? J. Eur. Econ. Ass. 2013, 11, 495-524. [CrossRef]

6. Leider, S.; Rosenblat, T.; Mobius, M.M.; Do, Q.-A. What do we Expect from our Friends? J. Eur. Econ. Assoc. 2010, 8, 120-138. [CrossRef] 
7. Branas-Garza, P.; Cobo-Reyes, R.; Espinosa, M.P.; Jimenez, N.; Kovarik, J.; Ponti, G. Altruism and Social Integration. Games Econ. Behav. 2010, 69, 249-257. [CrossRef]

8. Goeree, J.K.; McConnell, M.A.; Mitchell, T.; Tromp, T.; Yariv, L. The 1/d Law of Giving. Am. Econ. J. Microecon. 2010, 2, 183-203. [CrossRef]

9. Bezu, S.; Holden, S.T. Generosity and Sharing Among Villagers: Do Women Give More? J. Behav. Exp. Econ. 2015, 57, 103-111. [CrossRef]

10. Iversen, V.; Jackson, C.; Kebede, B.; Munro, A.; Verschoor, A. Do Spouses Realise Cooperative Gains? Experimental Evidence from Rural Uganda. World Dev. 2011, 39, 569-578. [CrossRef]

11. Berg, J.D. Trust, Reciprocity and Social History. Games Econ. Behav. 1995, 10, 122-142. [CrossRef]

12. Castilla, C. Trust and Reciprocity between Spouses in India. Am. Econ. Rev. 2015, 105, 621-624. [CrossRef]

13. Hoel, J.B. Heterogeneous Households: A within-subject Test of Asymmetric Information between Spouses in Kenya. J. Econ. Behav. Organ. 2015, 118, 123-135. [CrossRef] [PubMed]

14. Griener, B. The Online Recruitment System ORSEE 2.0-A Guide for the Organization of Experiments in Economics; Working Paper Series in Economics 10; Department of Economics, University of Cologne: Cologne, Germany, 2004.

15. Andreoni, J.; Sprenger, C. Estimating Time Preferences from Convex Budgets. Am. Econ. Rev. 2012, 102, 3333-3356. [CrossRef]

16. Fischbacher, U. z-Tree: Zurich Toolbox for Ready-made Economic Experiments. Exp. Econ. 2007, 10, 171-178. [CrossRef]

17. Chowdhury, S.M.; Joen, J.Y. Impure Altruism or Inequality Aversion?: An Experimental Investigation Based on Income Effects. J. Public Econ. 2014, 118, 143-150. [CrossRef]

18. Pew Research Center Social and Demographic Trends Webpage. Available online: http://www. pewsocialtrends.org/2008/09/25/women-call-the-shots-at-home-public-mixed-on-gender-roles-in-jobs / (accessed on 7 September 2018).

19. Dasgupta, U.; Mani, S. Only Mine or All Ours: Do Stronger Entitlements Affect Altruistic Choices in the Household. World Dev. 2015, 67, 363-375. [CrossRef]

20. Castilla, C. What's Yours Is Mine, and What's Mine Is Mine: Bargaining Power and Income Concealing Between Spouses in India. 2016. Available online: http:/ / pages.vassar.edu/lacdevconf2016/files/2016/08/ Whats-Yours-is-Mind-and-Whats-Mine-is-Mine-Bargaining-Power-and-Income-Concealing-BetweenSpouses-in-India.pdf (accessed on 12 August 2018).

21. Barnett, A.E.; Stum, M.S. Spousal Decision Making and Long-Term Care Insurance. J. Financ. Counsel. Plan. Educ. 2013, 24, 5-19.

22. Ferber, R.L. Husband-Wife Influence in Family Purchasing Behavior. J. Cons. Res. 1974, 1, 43-50. [CrossRef] 